\title{
PELATIHAN KARYA TULIS ILMIAH DAN PENGELOLAAN JURNAL ELEKTRONIK SEBAGAI MEDIA HALAQOH ILMIAH DI PESANTREN LUHUR
}

\author{
Idris $^{1 *}$, Arif Subekti ${ }^{2}$, Wahyu Djoko Sulistyo ${ }^{2}$ \\ idrismuhammad234@gmail.com \\ ${ }_{1}^{1}$ Prodi Pendidikan IImu Pengetahuan Sosial, Fakultas IImu Sosial, Universitas Negeri Malang \\ 2Jurusan Sejarah, Fakultas Ilmu Sosial, Universitas Negeri Malang \\ Diterima 23 Januari 2020, dipublikasikan 30 April 2020
}

\begin{abstract}
Abstrak
Karya tulis ilmiah dan publikasi merupakan produk yang menjadi tuntutan dalam dunia akademik. Halaqoh ilmiah merupakan salah satu program rutin yang dilaksanakan oleh pesantren Luhur untuk memberikan pemahaman dan pengalaman keilmuan kepada santri. Namun demikian, dalam pelaksanaannya, karya-karya yang dibuat dan dipresentasikan oleh santri pada kegiatan tersebut, belum tersusun sesuai dengan kaidah penulisan ilmiah. Oleh karena itu, diperlukan adanya pelatihan karya tulis ilmiah dan sekaligus pelatihan pengelolaan jurnal elektronik agar para santri bisa menulis sekaligus memberikan mereka media untuk mempublikasikan karya mereka dalam bentuk jurnal online yang bisa dinikmati dan dibaca oleh publik secara luas. Kegiatan pelatihan ini dilaksanakan di pondok pesantren Luhur dengan Tim Pengabdian menjadi narasumber pada kedua acara tersebut. Hasil dari kegiatan pelatihan ini sangat memuaskan, semua peserta anstusias dan memahami secara komprehensif materi pelatihan. Selain itu, bagi para santri yang menjadi perwakilan dalam pelatihan pengelolaan jurnal secara online. Evaluasi pasca pelatihan menunjukan bahwa tim editor dari pesantren dapat mengoperasionalkan sistem Open Journal System (OJS) dengan baik.
\end{abstract}

Kata Kunci: Pelatihan, Karya Tulis IImiah, Jurnal Elektronik, Halaqoh IImiah, Pesantren Luhur.

\section{PENDAHULUAN}

Karya ilmiah merupakan pemaparan suatu permasalahan ilmiah dengan logis, sistematis, dan dapat dipertanggungjawabkan secara empiris dan objektif (Syaefullah, 2015). Karya ilmiah tidak hanya mengandung gagasan ilmiah baik secara teoritis maupun empiris, akan tetapi ia juga merupakan produk dari kejelian, kecermatan, dan keuletan dalam proses kreatif menuangkan pemikiran dalam bentuk tulisan (Asik, 2015; Nurhayatin et al., 2018). Menulis Karya tulis ilmiah membutuhkan kematangan berpikir (Budiyono, 2012), penataan Bahasa yang teratur, logis, dan sistematis (Setiorini, 2010). Ada beragam bentuk dari karya tulis ilmiah seperti makalah, skripsi, tesis, disertasi, artikel ilmiah dan lain-lain (Jaedun, 2011; Kurniadi, 2017). Di dunia Pendidikan tinggi, mahasiswa sebagai bagian dari dunia akademik, tidak hanya akrab dengan karya tulis ilmiah (Kurniadi, 2017). Pada saat perkuliahan, mereka dituntut untuk membuat skripsi sebagai tugas akhir (Hariyati, 2012; Rahmiati, 2013). Namun demikian, tidak sedikit dari mereka sebenarnya belum mampu atau belum bisa dengan mudah menyusun karya tulis ilmiah dengan baik (Syahriyani, 2010; Wijayanti, 2017). Sehingga pada akhirnya, kebanyakan dari mereka melakukan tindakan plagiarisme yang merupakan kejahatan di dalam dunia akademik (Aziz et al., 2015; Santoso, 2015). Oleh karena itu, peningkatan keterampilan menulis karya tulis ilmiah menjadi hal yang sangat penting.

Pesantren Luhur menjadi salah satu Lembaga yang cukup signifikan di dalam menampung, mengembangkan, dan mendidik mahasiswa, baik dalam hal kegamaan maupun dalam hal kepenulisan. Pesantren ini terletak di antara tiga universitas negeri di Malang seperti Universitas Islam Negeri Maulana Malik Ibrahim, Universitas Brawijaya, dan Universitas Negeri Malang. Posisi yang strategis ini menempatkan Pesantren Luhur sebagai salah satu pemondokan yang diminati mahasiswa. Selain mahasiswa dari ketiga kampus tersebut, para santri juga berasal dari perguruan tinggi lainnya di Malang Raya seperti Universitas Muhammadiyah Malang, Politeknik Kesehatan Malang, Politeknik Negeri Malang, Sekolah Tinggi IImu Hukum, Universitas Islam 
Malang, dan Universitas Raden Rahmat. Oleh karena itu, publik menganggap bahwa pesantren ini merupakan pesantren yang khusus menampung mahasiswa yang ingin belajar agama, meskipun pada dasarnya ada juga santri yang tidak berasal dari perguruan tinggi.

Jumlah santri yang mendiami Pesantren Luhur pada bulan Agustus 2018 berjumlah 430 orang, dengan rincian 305 putri dan 125 putra. 87\% santri merupakan mahasiswa dari tiga perguruan tinggi negeri sekitar pesantren, sedangkan sisanya (13\%) merupakan mahasiswa dari pelbagai perguruan tinggi lainnya. Sementara tenaga pengajar (dewan asatidz) Pesantren Luhur berjumlah 12 tenaga, dengan rincian lima berpendidikan doktoral (Strata 3), empat bergelar magister (Strata 2), dan tiga bergelar sarjana (Strata 1).

Selain memprogramkan kegiatan rutin sebagaimana lazimnya pesantren di tempat lain, pesantren Luhur juga mengagendakan program harian halaqah setiap selesai jamaah shubuh dan istighotsah. Halaqah merupakan kegiatan dalam kelompok belajar yang berisi presentasi makalah yang dibebankan pada tiap santri, sementara para santri yang lain menjadi peserta yang menyimak. Sisi uniknya, varian topik yang dibahas dalam halaqah sangat beragam meliputi kajian ilmu agama (tauhid, figh, tashawuf, tafsir) dan ilmu umum (baik cabang sosial humaniora, seperti filsafat, hukum, sejarah, psikologi, maupun cabang eksakta seperti fisika, kimia, teknik dan lain sebagainya).

Program halaqah Pesantren Luhur ini secara rutin menghasilkan minimal dua makalah ilmiah dengan topik yang sama setiap hari aktif pesantren (Senin sampai dengan Sabtu). Hal ini sama artinya dengan 48 makalah ilmiah setiap bulannya. Potensi akademis ini, sejauh ini, baru dikelola dalam karya ilmiah berupa delapan jilid kliping/bendel makalah halaqah ilmiah berjudul "Percikan Ilmu Pengetahuan".

Kekurangan makalah ilmiah hasil kegiatan halaqah santri Pesantren Luhur adalah perihal belum adanya satu selingkung yang disepakati sebagai pedoman penulisan bersama. Karya satu pemateri, dengan pemateri yang lainnya, kurang dapat dinikmati dalam satu kumpulan karya ilmiah. Hal ini terutama sekali dilatarbelakangi oleh perbedaan institusi perguruan tinggi serta rumpun ilmu yang didalami oleh masing-masing pemateri. Selain itu, adanya inkonsistensi pada proses diskusi di forum halaqoh membuat kegiatan ini kurang berjalan dengan maksimal. Misalkan materi halaqoh dengan topik tashawwuf dipresentasikan oleh santri dari perguruan tinggi jurusan eksak dan di-review oleh senior dengan latar belakang pendidikan hukum.

Potensi produksi karya ilmiah yang dimiliki oleh Pesantren Luhur seyogyanya dapat didiseminasikan dalam lingkup yang lebih luas. Ini artinya, pemikiran santri atau mahasiswa dari kegiatan halaqah Pesantren Luhur sudah sepatutnya dikemas dan dikelola dalam platform yang murah, mudah, dan sesuai dengan perkembangan jaman, yakni electronic journal atau e-journal. Oleh karena ini, kegiatan pengabdian kepada masyarakat ini akan difokuskan pada karya tulis ilmiah dan pelatihan pengelolaan e-journal dengan menggunakan Open Journal System (OJS). Pelatihan karya tulis ilmiah dimaksudkan untuk memberikan wawasan dan pengetahuan di dalam menulis karya yang baik, yang sesuai dengan standar penulisan ilmiah. Sedangkan, pelatihan pengelolaan jurnal elektronik bertujuan untuk dokumentasi dan disseminasi karya santri.

Banyaknya hasil karya ilmiah yang dihasilkan dari kegiatan halaqah dan keperluan mendiseminasikan pemikiran santri Pesantren Luhur Malang menuntut adanya kebutuhan instalasi e-journal halaqah Pesantren Luhur. Ukuran prioritas tercermin dalam produksi karya ilmiah yang secara konsisten dihasilkan dalam kegiatan halaqah-12 karya perminggu, 48 perbulan, atau 576 pertahun-berbanding terbalik dengan masih sangat sederhananya pengelolaan dan minimnya aksesabilitas informasi yang sebenarnya dapat dimaksimalkan oleh khalayak akademis.

Solusi yang kami tawarkan untuk mengatasi permasalahan di Pesantren Luhur Malang ialah pelatihan karya tulis ilmiah dan pengelolaan jurnal elektronik dengan menggunakan OJS dari forum halaqah yang mereka laksanakan. Pelakasanaan kegiatan ini diawali dengan observasi, pendataan makalah yang masuk selama tahun 2015 - 2019, pelatihan karya tulis ilmiah bagi para santri, dan terakhir pelatihan pengelolaan jurnal elektronik (e-journal) dengan online journal system (OJS) bagi para pengurus pesantren.

Sasaran kegiatan ini adalah para santri agar mereka memiliki wawasan tentang penulisan karya ilmiah. Selain itu, pengurus Pesantren Luhur (majelis santri) juga dilatih untuk terampil di dalam mengelola jurnal secara online. Jurnal elektronik ini nantinya dapat dilanjutkan oleh kepengurusan selanjutnya secara mandiri dan berkelanjutan.

\section{METODE}

Metode pelaksanaan kegiatan pelatihan pengelolaan jurnal elektronik, secara umum, dibagi menjadi tiga tahapan kegiatan, yaitu pra kegiatan, pelaksanaan kegiatan, dan pasca kegiatan dengan rincian masing-masing tahapan sebagai berikut: 
1. Pra-Kegiatan

Tim melakukan survei awal ke Pesantren Luhur dan menjalin komunikasi dengan pihak Majelis Santri (pengurus harian pesantren) serta Sie Penelitian dan Pengembangan (Sie. Litbang). Di bawah Sie. Litbang terdapat tim halaqah yang menjadi koordinator kegiatan halaqah serta mendokumentasikan makalah. Selanjutnya tim mengajukan kerja sama kepada pengurus Pesantren Luhur dan tim halaqah sebagai pioner pengembang jurnal.

2. Saat Kegiatan Berlangsung

Kegiatan pelatihan akan dilakukan tiga tahap. Pertama yaitu pelatihan karya tulis ilmiah yang dilaksanakan sehari. Pada kegiatan ini, tim memberikan materi tentang kiat-kiat menulis dan juga mengenalkan materi tentang karya tulis ilmiah, khususnya artikel jurnal.

Tahap Kedua yaitu, pelatihan penyusunan editorial team dan pembentukan jurnal sebagai wadah aktualisasi ilmiah para santri khususnya dan khalayak pada umumnya. Pada kegiatan ini tim akan menyampaikan materi tentang dasar-dasar pembentukan dan penyusunan serta kriteriakriteria yang dibutuhkan dalam tim jurnal. Output dari kegiatan ini adalah terbentuknya tim jurnal yang akan mengawal seluruh proses editorial dalam pengelolaan jurnal.

Penyusunan editoral team akan melibatkan pihak internal pesantren dan pihak luar seperti perguruan tinggi yang menjadi tempat belajar santri-santri yang belajar di pesantren Luhur seperti UIN, UB, dan UM. Mereka akan dioptimalkan untuk mencari mitra bestari yang siap membantu keberlangsunan publikasi ilmiah yang selama ini telah dilaksanakan namun belum terorganisasi dengan baik dalam bentuk pengelolaan jurnal secara akademis.

Setelah semua susunan tim editorial jurnal telah terbentuk, selanjutnya output tersebut akan digunakan nanti dalam proses setting jurnal melalui platform OJS yang akan dilaksanakan pada kegiatan pelatihan kedua. Pembangunan rumah jurnal yang pertama ini akan menjadi bahan dalam kebiajakan dan pembuatan jurnal secara online melalui OJS.

Tahap ketiga dilakukan selama satu hari penuh dengan tujuan pelatihan pengelolaan elektronik jurnal dengan menggunakan OJS. Pada pelatihan tahap ini, peserta adalah semua tim editorial yang telah dibentuk sebelumnya dan akan dilatih. Hal pertama yang dilakukan padda bagian ini adalah menginstal OJS kedalam server yang telah disewa oleh pesantren atau dalam domain yang dimiliki pesantren. Selanjutnya, mereka juga akan dilatih untuk men-setting jurnal yang ada pada domain yang telah dibuat, me-layout dan membuat guideline, policy, serta template yang akan digunakan untuk paper yang akan diterbitkan dalam jurnal online tersebut.

Setelah semua proses setting dan layout telah dilakukan selanjutnya, mereka akan dilatih untuk mengoperasikan proses editorial seperti yang dijalankan pada proses offline. Mereka akan diperankan masing-masing peserta sebagai editor in chief, section editor, reviewer, layout editor, proofreader dan lain-lain. Pada proses ini nanti peserta akan dipastikan dapat mengoperasikan ejurnal dengan OJS melalui beberapa simulasi-simulasi yang akan dilaksanakan selama sehari, hingga benar-benar mereka bisa menjalankan system ejurnalnya secara mandiri.

3. Pasca Kegiatan

Setelah kegiatan pelatihan dilakukan, maka langkah selanjutnya adalah melakukan evaluasi, follow up, dan pendampingan. Hal ini dilakukan untuk melihat apakah peserta pelatihan bisa menerapkan hasil pelatihan. Evaluasi dilakukan dengan cara tanya jawab dan sharing untuk menindaklanjuti hambatan yang dialami peserta. Selanjutnya, tim pengusul akan melakukan follow up dan pendampingan kepada para tim editorial yang dibentuk untuk memastikan mereka dapat mengoperasikan dan melakukan penerbitan jurnal secara online sesuai dengan yang diharapkan bersama.

\section{HASIL DAN PEMBAHASAN Persiapan Pelaksanaan Pengabdian}

Kegiatan dalam persiapan pelaksanaan pengabdian ini meliputi perencanaan dan koordinasi dengan pihak terkait. Selain itu, pada tahap ini juga dilakukan pengurusan segala administrasi yang berkaitan dengan kelancaran pelaksanaan pengabdian, seperti pengurusan surat perijinan, permohonan pemimnjaman tempat, dan semua kegiatan persiapan lainnya yang berkaitan dengan kelancaran kegiatan pengabdian.

Kegiatan koordinasi, secara umum telah dilakukan beberapa kali, tepatnya telah dilakukan lima kali pertemuan dengan Yayasan Pesantren Luhur, baik dengan berkoordinasi dengan pimpinan pondok secara langsung, maupun berkoordinasi dengan pengurus pondok, selaku perwakilan yang mengurus segala sesuatu yang berkenaan dengan pelaksanaan kegiatan. Pertemuan pertama dilaksanakan di Pondok pesantren luhur, lokasi pengabdian, dengan dihadiri oleh tim pengabdian dari Universitas Negeri Malang bersama pimpinan pondok pesantren luhur. 
Pertemuan pertama membahas tentang maksud dan tujuan tim UM untuk melaksanakan pengabdian di Pesantren luhur berkaitan dengan pelatihan pengelolaan jurnal dengan menggunakan OJS 2 sebagai media yang produktif dan potensial untuk menyebarkan nilai-nilai keagamaan yang dikembangkan dan diajarkan oleh pesantren kepada khalayak. Pada pertemuan ini pimpinan pondok menyambut dengan positif dan sangat mendukung atas terlaksananya kegiatan yang telah direncanakan oleh tim. Selain itu, pimpinan pondok pesantren luhur menunjuk beberapa pengurus untuk menindak lanjuti maksud dan tujuan dari tim pengabdian dan sekaligus menunjuk orang yang bertanggung jawab atas terlaksananya kegiatan pelatihan tersebut.

Pertemuan kedua, tim bertemu dengan para pengurus pondok pesantren yang telah ditunjuk oleh pimpinan pesantren untuk membicarakan masalah teknis terkait pelaksanaan kegiatan pelatihan. Selain itu, pada pertemuan tersebut juga dibahas masalah penentuan waktu dan tempat pelatihan serta peserta pelatihan yang akan dihadiri oleh tim dari UM dan para santri. Pertemuan tersebut juga menghasilkan daftar kegiatan pendukung sebelum adanya pelaksanaan kegiatann pelatihan pengelolaan jurnal dengan menggunakan OJS, diantaranya adalah pemberian materi karya tulis ilmiah kepada para santri dan juga materi tentang pengenalan jurnal dan pengelolaan jurnal berbasis online.

Pertemuan ketiga dilakukan untuk membahas masalah pembentukan dan penyusunan editorial jurnal pesantren luhur, termasuk penentuan nama jurnal. Pada pertemuan ini juga dibahas masalah penyiapan bahan-bahan lainnya seperti uraian singkat tentang jurnal, kebijakankebijakan seperti open access, copyright holder, dan kabijakan lainnya. Selain itu, bahan-bahan lain yang juga perlu disiapkan oleh pihak pesantren adalah mengenai author guideline, template paper jurnal, dan juga petunjuk bagi reviewer.

Selanjutnya, untuk pertemuan keempat membahas mengenai berbagai hal yang perlu disiapkan sebelum pelaksanaan kegiatan pelatihan dilakukan seperti penyusunan modul pelatihan, pembentukan kepanitian di internal pesantren, dan instalasi OJS 2 pada website pesantren luhur. Pada pertemuan ini, tim tidak berhasil melakukan proses instalasi dikarenakan adanya perbedaan level Bahasa pemprogaman. Akhirnya, dilanjukan pada pertemuan selanjutnya untuk kembali melakukan proses instalasi OJS 2.

\section{Pelatihan Karya Tullis IImiah}

Santri atau Mahasiswa adalah calon pemimpin-pemimpin di masa depan. Mereka dituntut untuk mempunyai kecakapan di dalam berpikir kritis, dan membaca dan menulis secara analitis (Pawitasari et al., 2015). Hal tersebut dapat dimiliki oleh mereka melalui membaca karya-karya ilmiah yang dipublikasikan. Selain itu, mereka juga dituntut untuk memiliki kecakapan di dalam menuangkan gagasan dan pikirannya dalam bentuk karya tulis ilmiah yang terpublikasikan agar tersebar dan dapat memberikan manfaat kepada masyarakat luas. Kelemahan mahasiswa di dalam menulis karya ilmiah, khususnya artikel jurnal menurut Rosyadi (2016) disebabkan rendahnya minat baca, kurangnya penggunaan pustaka yang ada di perpustakaan yang dapat dijadikan tempat sumber referensi, minimnya varian bacaan (mereka hanya membaca buku yang berhubungan dengan perkuliahan), kurangnya pengetahuan tentang teknik dan kemampuan menulis, dan kurangnya pengetahuan tentang publikasi karya ilmiah pada jurnal-jurnal baik jurnal nasional aupun internasional. Oleh karena itu, kegiatan workshop dan pelatihan menjadi sangat penting bagi mahasiswa atau santri sebagai media mengembangkan diri.

Pelaksanaan kegiatan karya tulis ilmiah dimaksudkan untuk memberikan pemahaman dan wawasan yang luas kepada para santri terkait penulisan karya tulis ilmiah. Kegiatan ini dilaksanakan pada tanggal 11 Oktober 2019 di Pesantren Luhur. Kegiatan ini dihadiri oleh seluruh santri yang ada di Pondok Pesantren Luhur.

Acara pelatihan penulisan karya tulis ilmiah ini dibuka oleh Kyai Mansur dalam acara pembukaan. Selanjutnya, setelah acara dibuka oleh pimpinan Pesantren luhur, moderator mengambil alih kendali acara dan mempersilahkan pemateri untuk menyampaikan materi terkait karya tulis ilmiah. Materi penulisan karya tulis ilmiah ini membahas secara rinci mengenai bagaimana mahasiswa menyusun dan membuat artikel ilmiah.

Pemateri menguraikan dengan jelas bagaimana membuat judul, abstrak, dan kata kunci dalam penulisan artikel ilmiah. Selanjutnya, penulisan metode yang baik yang dapat dipahami dengan mudah dan dapat diduplikasi oleh pembaca yang ingin menggunakan metode yang sama. Selain itu, pemateri juga menjelaskan mengenai bagaimana menuliskan dan menyajikan hasil studi baik hasil studi eksperimen maupun studi pustaka. Uraian berikutnya menjelaskan berkaitan dengan penulisan pembahasan. Bagian ini merupakan bagian penting yang menjadi inti dari penulisan artikel karena berkaitan dengan poin-poin penting yang menjadi temuan di dalam studi. Selanjutnya, pemateri menguraikan terkait bagaimana menulis kesimpulan dan menyusun daftar 
pustaka beserta gaya selingkung masing-masing jurnal.

\section{Pelatihan Pengelolaan Jurnal Elektronik}

Publikasi ilmiah adalah proses yang di dalamnya terjadi komunikasi akademik yang dimaksudkan untuk mendiseminasikan hasil studi tertentu sebagai bentuk dari sumbangsih pada pengembangan ilmu pengetahuan (Fatmawati, 2013; Kristina, 2018). Penguasaan terhadap teknis operasional di dalam mengelola jurnal elektronik saat ini menjadi kemampuan yang sangat dibuthkan untuk menyediakan media yang baik untuk wadah dokumentasi dan disseminasi karyakarya mahasiswa atau santri yang ada di pondok pesantren luhur. Dengan demikian, pelatihan pengelolaan jurnal elektronik menjadi kebutuhan yang mendesak bagi lembaga pesantren untuk melatih para santri agar mampu secara mandiri dann berkelanjutan mengelola jurnal mereka sendiri.

Tahap kedua dalam kegiatan pengabdian ini, tim pengabdian melaksanakan kegiatan pelatihan pengelolaan jurnal elektronik berbasis OJS 2 yang sebelumnya sudah diinstal dan dilinkan pada website pesantren. Kegiatan ini dilaksanakan di Laboratorium IPS dengan pertimbangan jaringan dan koneksi internet yang cukup baik dibandingkan dengan melaksanakannya di Pesantren. Kegiatan ini dilaksanakan pada tanggal 18 Oktober dan dihadiri oleh 10 peserta, santri-santri pesantren luhur yang diutus dan akan menjadi editorial team jurnal di pesantren luhur.

Kegiatan pelatihan ini, secara umum, dibagi menjadi dua bagian yaitu pelatihan manajemen jurnal dan pelatihan operasional proses editorial. Pada bagian pertama pengelolaan manajemen jurnal berkaitan dengan bagaimana membuat dan mendesain tampilan jurnal. Bagian ini juga berisi tentang deskripsi jurnal, aim dan scope jurnal, kebijakan-kebijakan jurnal, copyright, informasi mengenai penerbit dan lain-lain.

Bagian kedua, dalam pelatihan pengelolaan elektronik jurnal adalah cara mengoperasionalkan proses editorial jurnal mulai dari penulis mengirimkan naskah artikel hingga artikel dipublikasikan. Dalam proses ini, setidaknya dimulai dari pengiriman artikel dari penulis, selanjutnya naskah dibaca secara sekilas oleh editor untuk memastikan paper sesuai atau masuk di dalam scope jurnal. Setelah itu, jika naskah dianggap sesuai, selanjutnya naskah didistribusikan kepada section editor, bagian editor yang memahami reviewer yang mana yang relevan dengan naskah tersebut. Pada langkah selanjutnya, setelah section editor memilih reviewer, maka naskah direview oleh reviewer. Rekomendasi reviewer atas naskah tersebut, baik revisi mayor, minor, diterima, atau ditolak merupakan bagian yang menentukan apakah naskah tersebut diterima, direvisi, atau ditolak. Proses yang dilakukan mulai dari penulis, editor, reviewer, penulis, dan kembali lagi kepada editor, semuanya dilakukan secara online dengan fungsi yang berbeda dari masing-masing peran yang telah dijelaskan (Prayudi et al., 2017).

\section{Respon dan Rencana Tindak Lanjut}

Pasca pelaksanaan kegiatan pelatihan pengelolaan jurnal elektronik dengan menggunakan OJS 2, tim pengabdian menyebarkan angket berkenaan dengan respon peserta kegiatan terhadap pelaksanaan kegiatan pelatihan yang dilaksanakan oleh tim pengabdian. Selain itu, pada kegiatan ini juga, peserta meminta tim pengabdian untuk melakukan rencana tindak lanjut (RTL) mengenai pendampingan penerbitan jurnal di pesantren luhur untuk edisi pertama, volume pertama. Berikut ini uraian berkaitan dengan hasil angket yang diisi oleh peserta kegiatan.

Pesantren luhur merupakan pesantren mahasiswa yang para santrinya berasal dari berbagai perguruan tinggi yang ada di Kota Malang. Gambar 1 menunjukan bahwa peserta kegiatan yang merupakan para santri pesantren luhur didominasi oleh mahasiswa Universitas Brawijaya dan UIN Maulana Malik Ibrahim dengan persentase $40.5 \%$ dan 33.3\%. Selanjutnya, persentase peserta yang hadir dari mahasiswa Universitas Negeri Malang sebanyak $21.4 \%$. Sedangkan sisanya sebesar $4.8 \%$ berasal dari universitas-universitas lain yang ada di Kota Malang. Data berkaitan dengan hal tersebut dapat dilihat pada gambar berikut ini. 


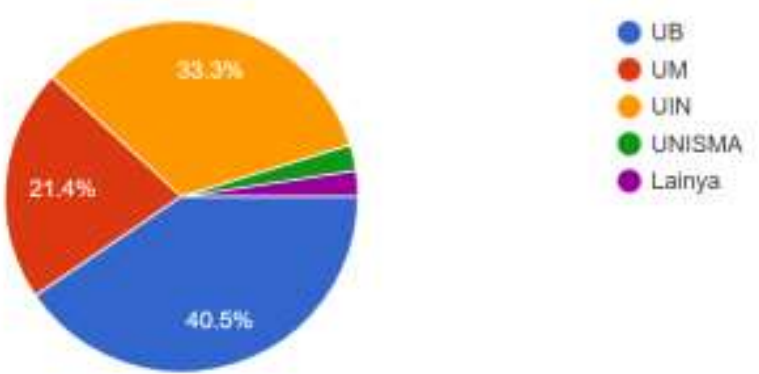

Gambar 1. Asal Peserta Pelatihan

Berkaitan dengan pengalaman menulis karya tulis ilmiah, dari 42 peserta kegiatan pengabdian, hanya ada $33.3 \%$ yang mengatakan tidak pernah menulis karya ilmiah. Sisanya, sebanyak $59.5 \%$ dan $7.1 \%$ pernah dan bahkan sering membuat karya tulis ilmiah, seperti yang ditunjukan pada gambar dibawah ini.

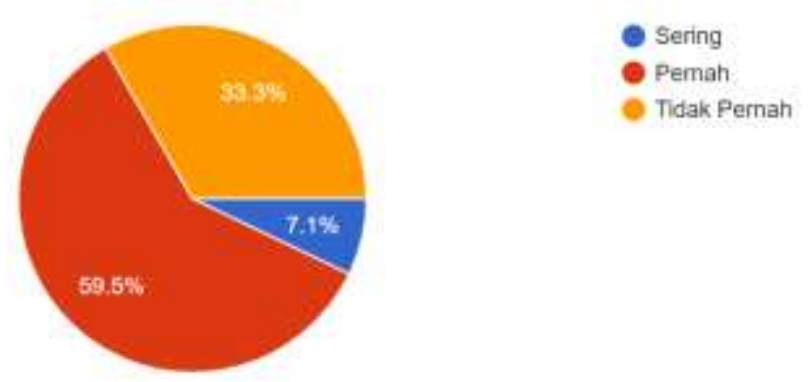

Gambar 2. Pernah Menulis Karya Tulis IImiah

Selanjutnya, berkaitan dengan peluang akses artikel ke jurnal internasional secara online. Mayoritas dari peserta kegiatan pelatihan pengelolaan jurnal elektronik dengan menggunakan OJS 2 ini adalah sangat bervariasi. Mereka yang tidak pernah sama sekali mengakses paper internasional secara online sebanyak $11.9 \%$ sedangkan sisanya kadang-kadang $(21.4 \%)$, sering (38.1\%), dan sangat sering (28.6\%).

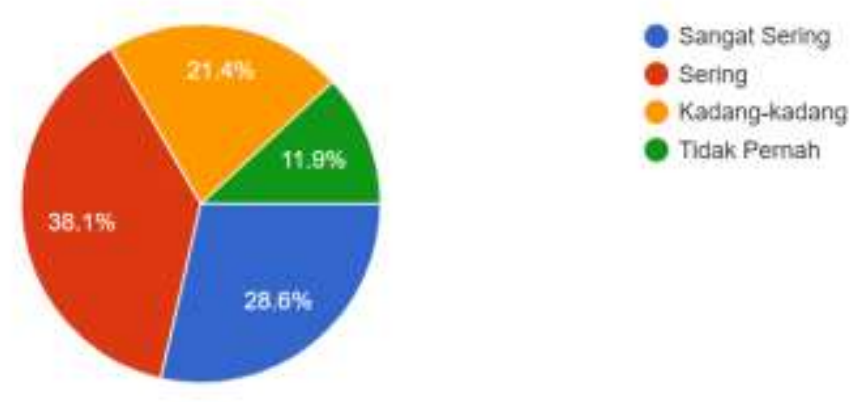

Gambar 3. Akses Artikel IImiah secara Online

Untuk mengetahui pemahaman para peserta kegiatan terhadap open journal system yang menjadi platform mayoritas pengelola jurnal baik nasional maupun internasional. Tim juga menanyakan pengetahuan mereka terkait pengelolaan jurnal secara online dan hasilnya cukup mengejutkan, ada sebanyak $35.7 \%$ dari peserta kegiatan yang sama sekali belum mengetahui tentang sistem jurnal online tersebut. Namun demikian, sebanyak $57.1 \%$ para peserta memahami dengan jelas terkait OJS. Hal ini dapat dilihat pada gambar berikut. 


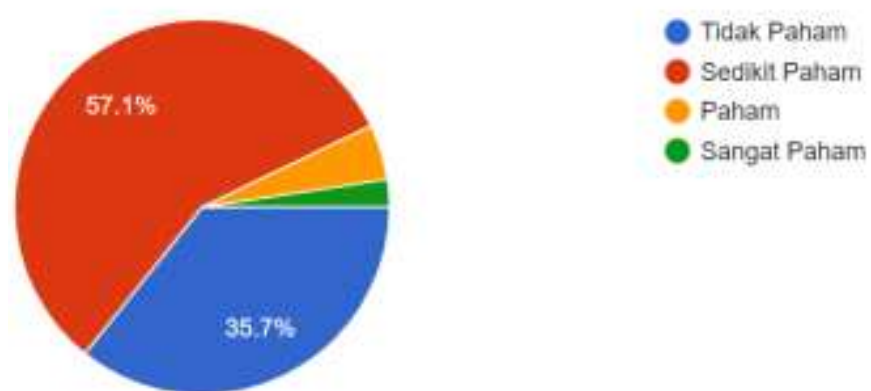

Gambar 4. Pemahaman terhadap OJS

Pasca pelaksanaan pelatihan, berdasarkan data yang terekap, ada sebanyak $61.9 \%$ dari keseluran peserta yang mengikuti kegiatan menyatakan paham. Dengan demikian dapat disimpulkan lebih dari separuh peserta telah memahami dengan baik materi yang disampaikan oleh tim pengabdian. Dengan persentase data yang dapat dilihat pada gambar sebagaimana berikut.

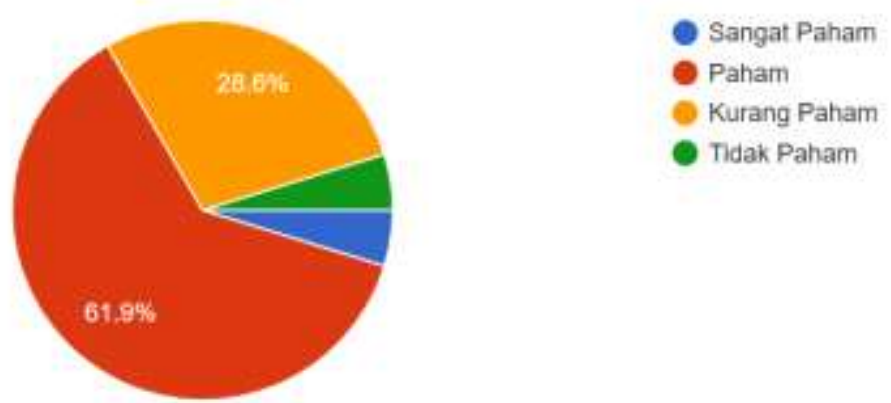

Gambar 5. Pemahaman setelah Pelatihan

Berkenaan dengan keinginan untuk memiliki rumah jurnal sendiri, dari keseluruhan peserta atau santri dari pesantren luhur menyatakan bahwa mereka sangat menginginkan untuk membuat rumah jurnal sendiri dengan persentase $51.2 \%$. Sedangkan yang lainnya ada yang menjawab ingin (31.7\%), cukup (14.6\%), dan hanya ada sebesar $2.4 \%$ yang menyatakan tidak ingin memiliki rumah jurnal sendiri. Hal ini bisa juga dikatakan bahwa secara garis besar, para santri menginginkan mempunyai rumah jurnal sendiri.

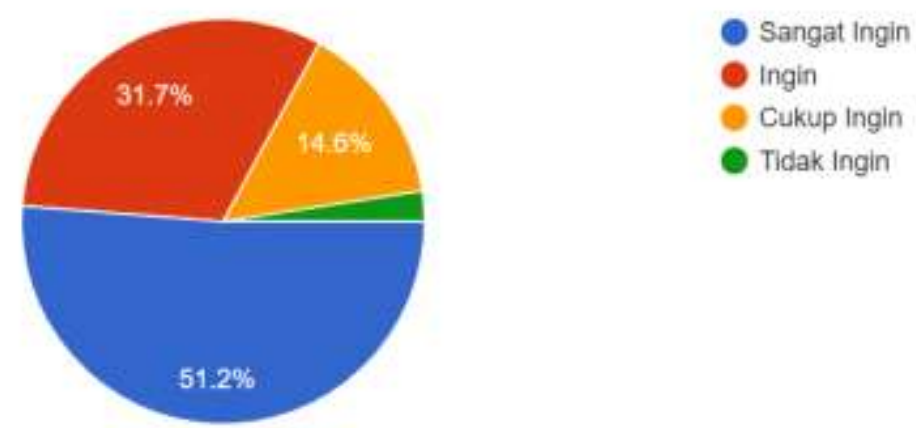

Gambar 6. Keinginan memiliki Rumah Jurnal Online

Pada pertanyaan selanjutnya, berkaitan dengan manfaat pelatihan bagi pemahaman para peserta, menunjukan bahwa kebanyakan mengatakan mereka mendapatkan pemahaman baru dan wawasan baru terkait dengan pengelolaan jurnal yang dikelola secara elektronik, dengan persentase $85.7 \%$ dan $11.9 \%$. data dapat dilihat sebagaimana berikut. 


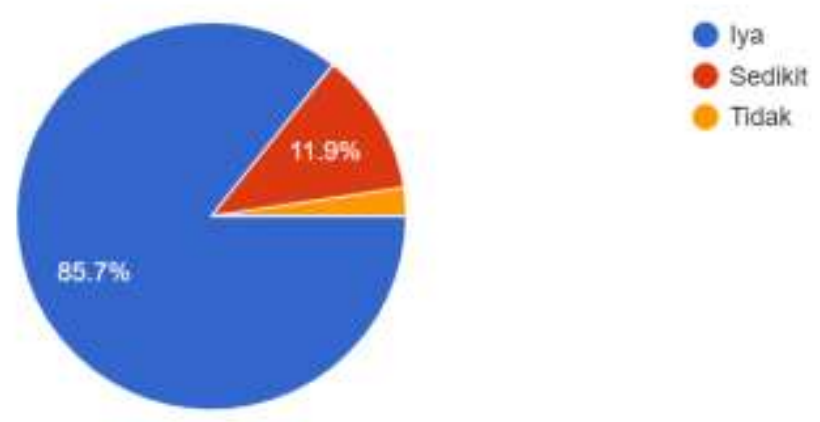

Gambar 7. Pelatihan memberikan pemahaman baru

Berdasarkan data yang dikumpulkan dari para peserta pelatihan yang merupakan para santri dari pondok pesantren luhur berkaitan dengan motivasi menulis karya ilmiah, sebanyak 40.5\% dan $33.3 \%$ menyatakan mempunyai motivasi besar dan sangat besar untuk mencoba menulis artikel ilmiah. Sedangkan, sisanya sebanyak $23.8 \%$ tidak terlalu termotivasi atau tidak terlalu tertatik untuk menulis artikel ilmiah.

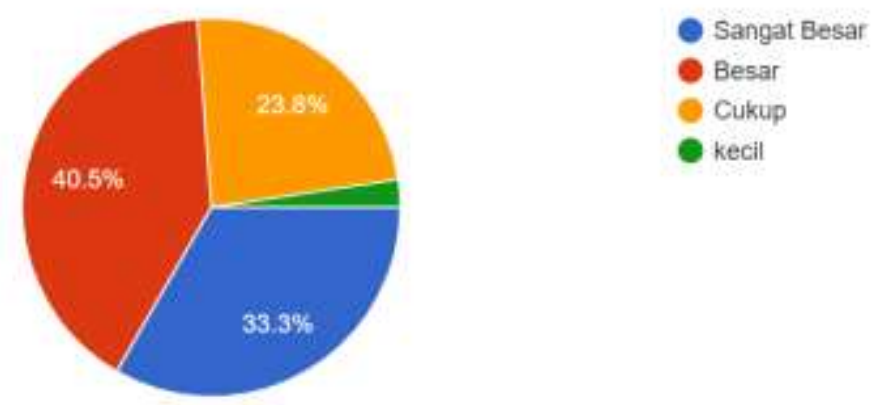

Gambar 8. Motivasi menulis Artikel ilmiah

Berkaitan dengan keinginan mempunyai jurnal sendiri, dari keseluruhan peserta $81 \%$ menyatakan ingin mempunyai jurnal sendiri pada tahun ini yaitu tahun 2019. Sedangkan, sisanya sebesar 19\% menyatakan ingin memiliki jurnal sendiri pada tahun depan, yaitu tahun 2020.

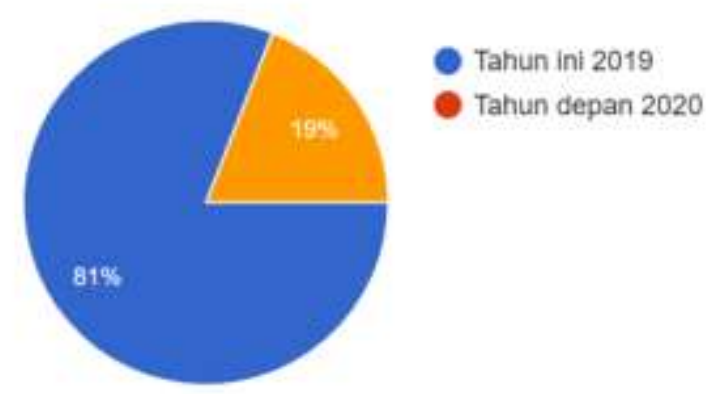

Gambar 9. Harapan memiliki Jurnal Sendiri

Selanjutnya, berkaitan dengan kepuasan atas pelaksanaan pelatihan pengelolaan jurnal elektronik dengan menggunakan OJS, secara berturut-turut, $69 \%$ dan $16.7 \%$ menyatakan puas dan sangat puas dengan pelaksanaan pelatihan. Sedangkan, sisanya $14.3 \%$ menyatakan kurang puas. Hal ini mengindikasikan secara garis besar, peserta merasa mendapatkan manfaat yang besar atas terlaksananya pelatihan pengelolaan jurnal elektronik dengan menggunakan OJS. Data berkaitan dengan hal ini dapat dilihat pada gambar sebagai berikut. 


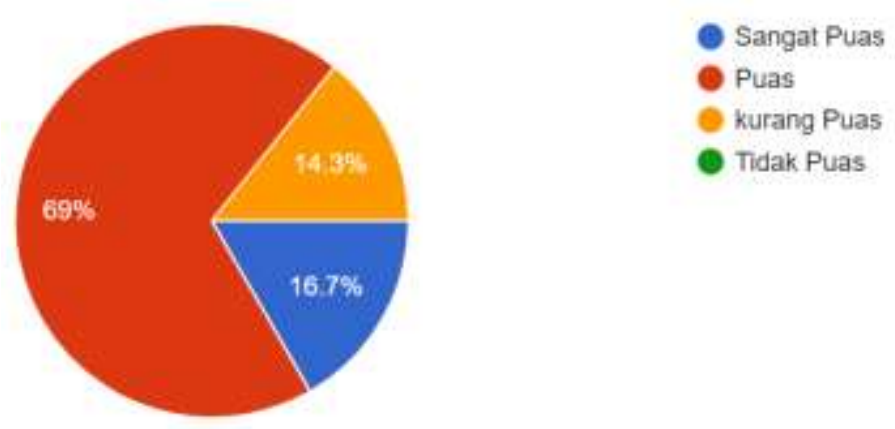

Gambar 10. Kepuasan atas pelaksanaan pelatihan

Berkenaan dengan rencana tindak lanjut atas pelaksanaan pengabdian berupa pelatihan pengelolaan jurnal elektronik dengan menggunakan OJS 2, mayoritas peserta manganggap perlu dilakukan follow up atas manajemen pengelolaan penerbitan jurnal secara online. Dari keseluruhan peserta, hampir $90 \%$ lebih menyatakan perlu dilakukan pendampingan hingga mereka benar-benar bisa melakukan dan mengoperasionalkan proses editorial sampai satu terbitan pertama.
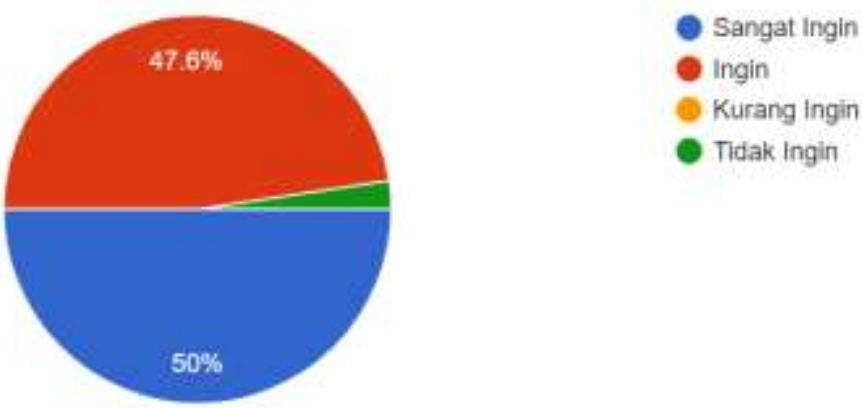

Gambar 11. Rencana Tindak Lanjut

Berdasarkan hasil evaluasi secara non formal dengan beberapa peserta yang menjadi utusan dari pengelolan jurnal Lunar, yaitu calon jurnal pondok pesasntren luhur, tim pengabdian akan melakukan pendampingan secara optimal dan berkelanjutan. Oleh karena itu, pasca kegiatan pelatihan, tim pengabdian akan menyusun jadwal diluar waktu pengabdian yang diberikan untuk memberikan pendampingan kepada para santri di dalam memproses dan menerbitkan jurnal mereka.

\section{KESIMPULAN}

Kegiatan pelatihan karya tulis ilmiah dan sekaligus pelatihan pengelolaan jurnal elektronik sebagai media pada Halaqoh pondok pesantren Luhur, secara umum, terlaksana dengan baik dan sesuai dengan yang diharapkan. Kegiatan pelatihan karya tulis ilmiah diikuti secara antusias oleh para santri yang berasal dari berbagai Univesitas di Kota Malang. Selain itu, pelatihan pengelolaan jurnal elektronik sebagai kegiatan inti dalam pengabdian ini juga berjalan sesuai dengan yang diharapkan. Dari beberapa peserta perwakilan pesantren yang dilatih sebagai wakil untuk selanjutnya menjadi tim pelaksana jurnal di pesantren Luhur menggap pelatihan ini sangat bermanfaat bagi mereka untuk belajar menjadi tim editor jurnal yang dikelola secara online. Pihak pesantren maupun santri juga meminta untuk diberikan pendampingan secara intens dalam rangka melakukan penyuntingan dalam proses editorial hingga mereka berhasil menerbitkan satu nomor tebitan untuk berikutnya.

\section{DAFTAR PUSTAKA}

Asik, N. (2015). Peningkatan Kemampuan Menulis Karya Ilmiah Melalui Pendekatan Kolaboratif. BAHTERA: Jurnal Pendidikan Bahasa dan Sastra. Vol. 14, No. 2. https://doi.org/10.21009/BAHTERA.142.06. 
Aziz, L. A., Irhandayaningsih, A., \& Kurniawan, A. T. (2015). Upaya Perpustakaan dalam Mengurangi Plagiarisme pada Karya Ilmiah Mahasiswa (Studi Kasus Di UPT Perpustakaan UNIKA Soegijapranata). Jurnal IImu Perpustakaan, Vol. 4, No. 3, hlm. 1-13.

Budiyono, H. (2012). Pengembangan Paragraf dan Kualitasnya pada Karya Tulis Ilmiah Mahasiswa Magister Teknologi Pendidikan Program Pascasarjana Universitas Jambi. Tekno-Pedagogi, 2(2), hlm. 51-64.

Fatmawati, E. (2013). Gerakan open access dalam mendukung komunikasi keilmuan. Visi Pustaka, 15(2), hlm. 96-106.

Hariyati, R. M. (2012). Survey Kinerja Dosen Pembimbing Skripsi dan Kualitas Skripsi Mahasiswa Akuntansi STIE Malangkucecwara. Jurnal Dinamika Akuntansi, Vol. 4, No. 2. hlm. 121128.

Jaedun, A. (2011). Pengembangan profesionalisme guru melalui penulisan karya tulis ilmiah. Prosiding Seminar karya Tulis IImiah dan PTK, hlm. 1-15.

Kristina. (2018). Menjadi scholarly communication librarians. Pustabiblia: Journal of Library and Information Science, Vol. 2, No. 2, hlm.183-194.

Kurniadi, F. (2017). Penulisan karya tulis ilmiah mahasiswa dengan media aplikasi pengolah kata. AKSIS: Jurnal Pendidikan Bahasa dan Sastra Indonesia, Vol. 1, No. 2, hlm. 267-277. https://doi.org/10.21009/AKSIS.010208

Nurhayatin, T., Inggriyani, F., \& Ahmad, A. (2018). Analisis keefektifan penggunaan kalimat dalam karya tulis ilmiah mahasiswa pendidikan guru sekolah dasar. Jurnal Pendidikan Sekolah Dasar. Vol. 4, No. 1, hlm. 102-114. https://doi.org/10.30870/jpsd.v4i1.2911

Pawitasari, E., Mujahidin, E., \& Fattah, N. (2015). Pendidikan Karakter Bangsa dalam Perspektif Islam (Studi Kritis Terhadap Konsep Pendidikan Karakter Kementerian Pendidikan \& Kebudayaan). Ta'dibuna: Jurnal Pendidikan Islam, Vol. 4, No. 1. hlm. 1-20. https://doi.org/10.32832/tadibuna.v4i1.573

Prayudi, M. A., Vijaya, D. P., \& Ekawati, L. P. (2017). Pengembangan sistem informasi manajemen pengelolaan dan penerbitan jurnal ilmiah jurusan akuntansi program S1. Proceeding TEAM, 2, hlm. 589-604.

Rahmiati, R. (2013). Problematika Mahasiswa dalam menulis karya ilmiah. Jurnal Adabiyah, Vol. 13, No. (2), hlm. 160-175.

Rosyadi, R. (2016). Jurnalistik Populer: Teknik Penulisan Berita, Opini, Artikel Populer, Artikel IImiah, Menghindari Plagiat, dan Melindungi Hak Cipta Karya Tulis. UIKA Press.

Santoso, H. (2015). Pencegahan dan penaggulangan plagiarisme dalam Penulisan Karya IImiah di Lingkungan Perpustakaan Perguruan Tinggi. Perpustakaan UM, hlm. 1-17.

Setiorini, R. A. (2010). Analisis penggunaan tata bahasa indonesia dalam penulisan karya tulis ilmiah: Studi kasus artikel ilmiah. LIPI, hIm. 16-24.

Syaefullah, A. (2015). Prinsip Dasar Penyusunan dan Penulisan Karya Tulis. PT. Grasindo.

Syahriyani, A. (2010). Optimalisasi budaya literasi di kalangan mahasiswa: Upaya meretas komunikasi global. Jurnal UI untuk Bangsa Seri Sosial dan Humaniora, 1, hlm. 68-78.

Wijayanti, A. (2017). Penerapan collaborative writing untuk meningkatkan keterampilan kerjasama dan motivasi mahasiswa pada mata kuliah penulisan karya tulis ilmiah. SOSIOHUMANIORA: Jurnal IImiah IImu Sosial dan Humaniora, Vol. 2, No. 1, hlm. 124134. https://doi.org/10.30738/sosio.v2i1.495. 